\title{
Sub-pixel Classification of Land Use Using Temporal Profile of NDVI
}

\section{NDVI の時間変化特性を用いた土地利用のサブピクセル分類}

\author{
Satoshi UCHIDA* \\ 内田諭
}

\begin{abstract}
In order to obtain the more detail land use information for wide area, the author examined sub-pixel classification method, which would be applied to coarse spatial resolution data such as NOAA/AVHRR. This method employs the features that each land use shows specific temporal profile of NDVI. Estimation of winter wheat cropped area and other land uses for the case study site located in the suburban area of Beijing in China was generally coincident with the results obtained from LANDSAT/TM data. The author also proposed an index, which evaluated appropriateness of combination of temporal data used in this method. This index was examined and proved to improve efficiency of process of sub-pixel classification. Although the method has not yet been established from the practical point of view, it can be expected to contribute to compilation of dataset of land use for global and regional scales.
\end{abstract}

\section{和文要旨}

広域のより精緻な土地利用情報を得るため, NOAA/AVHRR 等の低空間分解能デー夕に適用され るサブピクセル分類手法について検討を行った。ここ では, 土地利用毎に NDVIの時間変化特性が特徵的で あるという性質を用いている。中国北京近郊に位置す る対象地域における冬小麦作付域及びその他の推定を 試みたところ，LANDSAT/TM データによる分類結 果と概して一致することを確認した。また，この手法 において時系列データの組み合わせの適性度を評価す るための指標の提案を行った。この指標の検証と活用 方法の調查を行い，サブピクセル分類の効率性向上に 寄与するものであることを示した。本手法は，現段階 ではルーチン化されるような確立されたものではない が，今後，地球規模や広域の土地利用データセットの 整備に向けて有効に活用されることが期待できる。

*国際農林水産業研究セン夕一環境資源部

Environmental Resources Division, Japan International Research Center for Agricultural Sciences

干305-8686 茨城県つくば市大わし $1-2$

1-2 Ohwashi, Tsukuba, Ibaraki 305-8686, Japan

「写真測量とリモートセンシング」VOL. 40, NO. 1, 2001

\section{Introduction}

Issues on global environment have been argued for these decades. One of the most crucial issues must be the subject about the changes of population supporting capacity by agricultural food production, therefore information on land use as well as physical conditions of land should be collected and compiled so as to be used for models of environmental changes. Land use data filed as statistics by administrative unit involves insufficient information of characteristics of spatial distribution. By this background remote sensing could be recognized that one of the efficient technology to collect land use data in both spatial and temporal aspect.

In general the recurrent period of observation of high spatial resolution satellite data is longer than optimized period of crop growth monitoring and this feature makes limitation of monitoring of agricultural land use over continuous years. On the other hand low spatial resolution data such as NOAA/AVHRR has a potential to monitor agricul- 
tural land use in terms of temporal resolution, however it cannot properly indicate the distribution of land use, which might be compared with statistics data to verify the accuracy of estimation.

In order to utilize low spatial resolution data more effectively, a method of sub-pixel classification has been examined. A linear mixture model for spectral band data was applied by, e.g., Cross et al. ${ }^{11}$ to discriminate forest area, Holben and Shimabukuro $^{2)}$ to discriminate soil and vegetation. For the discrimination of agricultural land use types, multi -temporal features including NDVI changing pattern were used by, e.g., Quarmby et $a l^{3}{ }^{3}$, PuyouLascassies et $a l_{.}{ }^{4}$, Kerdiles and Grondona ${ }^{5}$, Ouaidrari et $a l .{ }^{6}$. This method was also examined in focussing on spatial variability by Faivre and Fischer $^{7)}$ and on estimation of end-member by Oleson et $a l^{8}{ }^{8}$. An approach to extract crop parameters from coarse resolution satellite data was implemented by, e.g., Fischer ${ }^{910)}$, Moulin et al. ${ }^{11)}$. This approach did not directly aimed at sub-pixel classification, however the combination of concept of linear mixture model and crop growth model should be feasible method to obtain quantitative information of agricultural land use.

This study has two major objectives as described in the followings. One is to examine applicability of linear mixture model of NDVI for sub-pixel classification mainly focussing on discrimination of agricultural land use in major crop production area. The other is to develop a method of sub-pixel classification from operational viewpoint, which facilitates to compile dataset of land use for large scaled target area.

\section{NDVI characterization by land use}

Land use categories can be defined rather arbitrarily according to the objective of theme. In case of estimating sustainability of agricultural land use, agronomists pay much attention on detail cropping pattern and methods of management but macro -environmental scientists usually do not concern the difference of variety of crops. In this study the term of land use would be followed by the concept of latter viewpoint.

Temporal changes of NDVI are characterized by especially agricultural land use type. Hence it is probable to discriminate land use using NDVI if an appropriate approach is established. In case of annual crop, its life cycle from seeding to harvest typically continues for three or four months and rate of temporal change is faster than that of forest or grassland area. The peak value of NDVI for cropped area may indicate a similar level compared with dense forest, however pattern of temporal profile shows evidently different features in timing and rate of increase and decrease.

The author attempted to characterize the temporal change of NDVI for rainfed agricultural area in Pakistan $^{12)}$ and India ${ }^{13)}$. These examples were cases for the semi-arid tropics where cropping season was limited in the narrow range of time in association with the timing of rainy season. For the agricultural land use in the temperate region it may have the more complex feature in terms of cropping system compared with the case in the semi-arid tropics. However if we focus on cultivation of major grain crops, cropping pattern in both temporal and spatial aspect would be systematically explained.

\section{Methods}

The basic assumption of this research lies on linear mixture modeling of NDVI as a function of time $t$ expressed in the followings.

$N D V I(t)=\sum_{i=1}^{n} \rho_{i} N D V I_{i}(t)$

where $\rho_{i}$ is the probability density of area of land use item $i$ in the pixel in the condition of $\sum_{i=1}^{n} \rho_{i}=1$. This formula can be solved if $(n-1)$ temporal data are given.

This method is supposed to be applied to NOAA/ AVHRR or equivalent spatial resolution data. From the practical point of view, temporal changes of NDVI for each land use cannot be uniquely defined 
due to not only atmospheric effects on radiometric characteristics but also growing conditions affected by various environmental factors. The end-member of $N D V I_{i}(t)$, which is the value at the pixel wholly occupied by land use item $i$ when time is $t$, can be estimated if spatially more detail land use information at the time of observation is available. Many studies adopted by linear mixture modeling for sub -pixel classification have employed high spatial resolution satellite data such as SPOT/HRV or LANDSAT/TM as referenced land use information. In this study it is assumed that the end-member value, which is obtained at specific site, can be used for other sites where physical and land use conditions are similar.

When a linear mixture modeling formula is solved, negative value of probability density may come to appear. This is treated by addition of values so as to be zero for the minimum probability density of land use items and thereafter by scaling to become one as summation of total probability density.

The selection of combination of $(n-1)$ temporal data is another significant problem for solving the formula. NDVI calculated from satellite data includes unexpected signals induced from complex- ity of surface conditions and it causes fluctation of value. If the selection of temporal combination is inappropriate, a large scale of error of estimation may be generated. In this paper the author proposes a method to evaluate the appropriateness of selection of temporal combination.

Figure 1 schematically illustrates this method applied to the case comprising three land use items. Solution, which represents the probability density of each land use, is represented as components value at cross point of two iso-NDVI lines on the plane shown by triangle, of which summation of values is one. In this figure iso-NDVI line is defined as trajectory of points, which have the same NDVI value under various constitutional combination of land use items. Proposed index, Index of Discrimination, can be calculated as an area of shaded part in the figure, where width of cross section $d_{1}$ and $d_{2}$ are inverse value of gradient of iso-NDVI lines, respectively. The smaller value of this index shows the better temporal combination to estimate the portion of each land use item in the pixel. In other words, if two iso-NDVI lines have steep gradient and tend to be crossed perpendicularly, the solution would be stable.

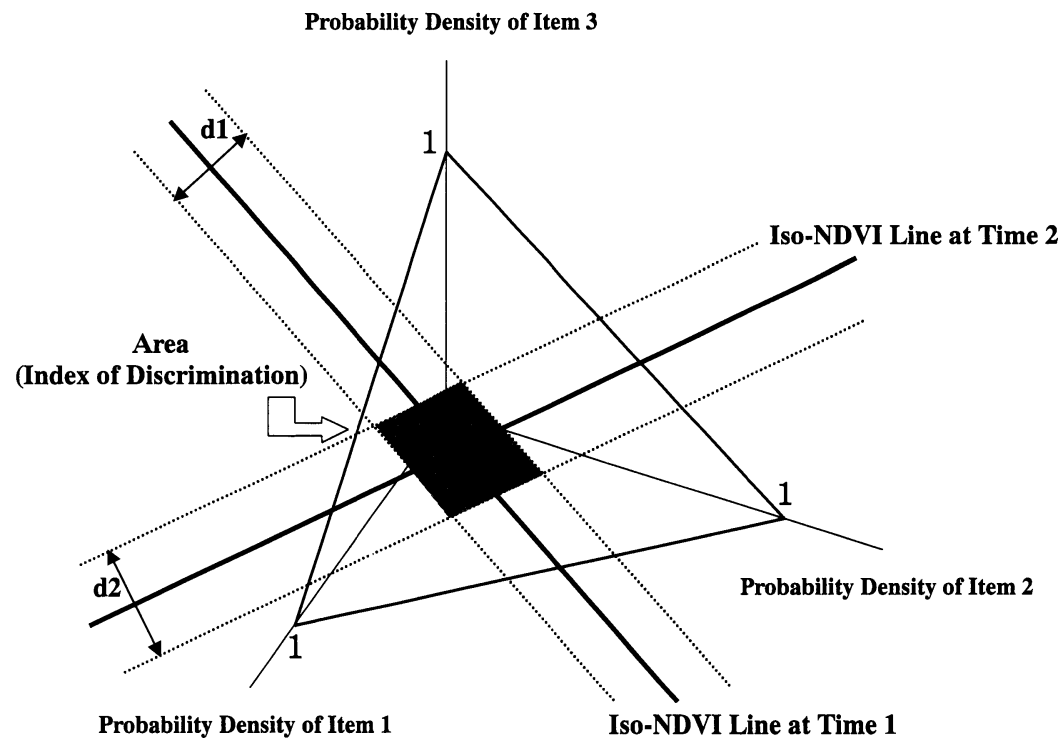

Figure 1 Schematic diagram of obtaining Index of Discrimination 


\section{Example for case of winter wheat area in China}

\subsection{Study site}

Study site is located in the eastern part of Beijing city including northern part of Tongxian district as shown in Figure 2. Agricultural activity of this area can be characterized in general by two dominant grain food crops of wheat in winter cultivation and maize in summer. Winter wheat is seeded in October and harvested in May, on the other hand, maize seeded in June and harvested in September. In summer season rice is also cultivated partially depending on the condition of irrigated water. Recent land use changes of this area is also characterized by the influence of urbanization. According to the analysis using LANDSAT/TM data by the author, area of urban settlement and constructions has been increased from $7.5 \%$ in 1984 to $22.1 \%$ in 1997 .

\subsection{Data}

In this research 10-day composite NDVI data produced from NOAA/AVHRR for the year of 1992 by U.S. Geological Survey ${ }^{14)}$ were employed to esti-

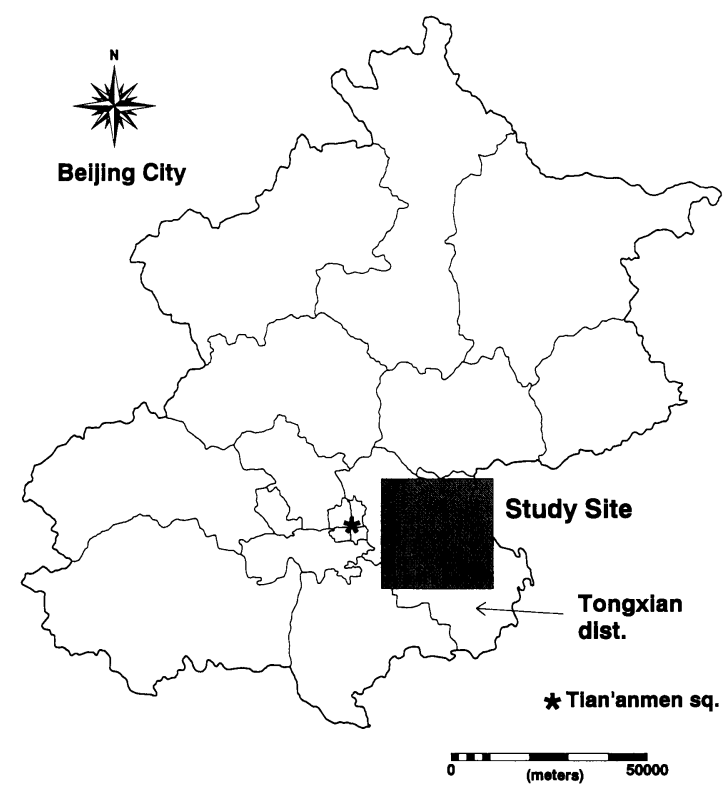

Figure 2 Location of study site mate the probability density of land use items in the pixel. The author also employed LANDSAT/TM data (Path: 123, Row: 32) for the purpose of obtaining end-member value as well as examining seasonal change of NDVI.

\subsection{Temporal profile of NDVI}

April and May are the most active season in terms of vegetation vigorous of winter wheat and the level of NDVI in these months exceeds to that of other land use. This feature should be confirmed by examining seasonal change of NDVI for each land use type. For this purpose following procedures were performed. First LANDSAT/TM data observed in April or May was classified by supervised classification method. This result was reclassed into five classes, i.e., cropped, mixed vegetation, bare land, urban and water. Cropped area was assumed to be almost identical with winter wheat cultivation area. Mixed vegetation area consisted of rural settlement, house garden, street trees, etc. The next step was to overlay multi-temporal classification data to extract invariably classified portion.

Figure 3 shows temporal profile of NDVI calculated from LANDSAT/TM data representing for land use item, which was invariably classified as mentioned above. In this figure cropped area was divided into two categories, i.e., before 1989 and after 1990, because yield level was significantly different each other due to the increase of fertilizer application during this period. It is evident that cropped area has distinctive maximum of NDVI in April to May and subsequent sharp drop. In mixed vegetation area temporal profile of NDVI shows more gentle increase tendency and no distinctive maximum in spring season. Both of bare land and urban areas represent low value of NDVI similarly in spring season but behaviors in summer season are inconsistent.

\subsection{Decision of end-member value}

End-member value of NDVI for a land use item would be obtained from relation between probabil- 


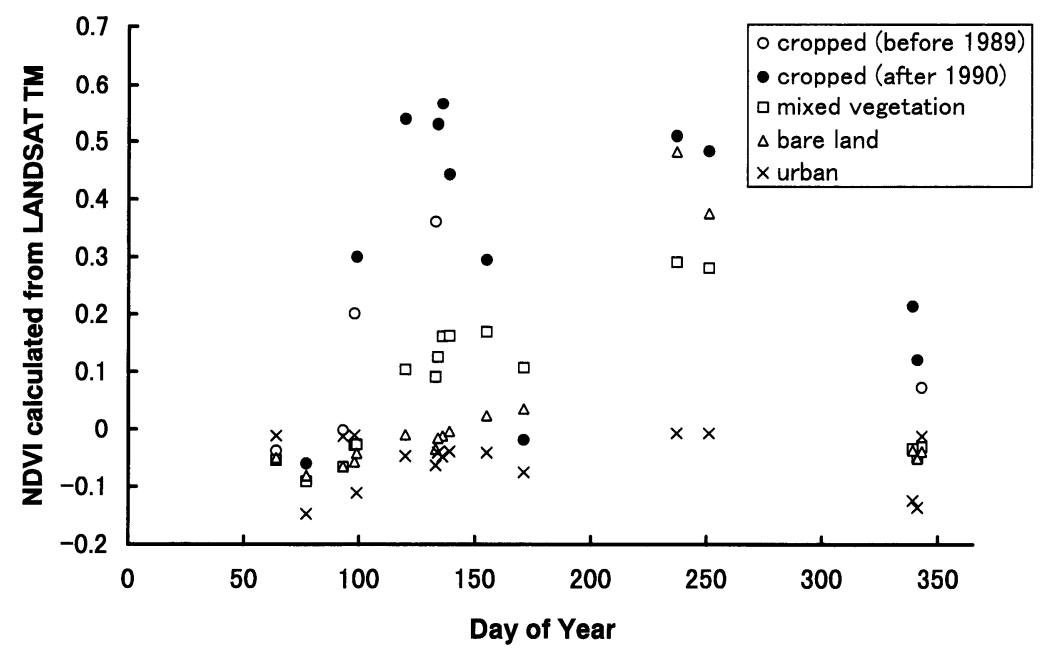

Figure 3 Temporal profile of NDVI for land use items calculated from LANDSAT/TM

ity density of portion of objective item in the pixel and NDVI value. This is assumed that NDVI of the pixel would be expressed by linear combination of contributions by the proportional portion of each land use item.

Figure 4 shows this relation for three different temporal cases from April to June, of which land use data was classified from LANDSAT/TM taken on 18 May in 1992. In order to obtain data shown in this figure, first, value at an objective land use item set as one and others as zero. Probability density of an objective land use was obtained by calculation of average of this value within 37 by 37 pixels window, then it was reclassed with an interval of 0.1 into groups shown by symbols in Figure 4. End-member value can be estimated as the value if probability density is equal to one. For this case the author draws a linear regression line for the data, of which probability density exceeds 0.4 , and extrapolates it to the value of one of probability density.

Figure 5 shows how end-member values change in temporal domain for the season during growing to harvesting of winter wheat. This feature has naturally similar characteristics as that shown in Figure 3 , even if spatial resolutions of original data are different each other.

(a) middle ten days of April

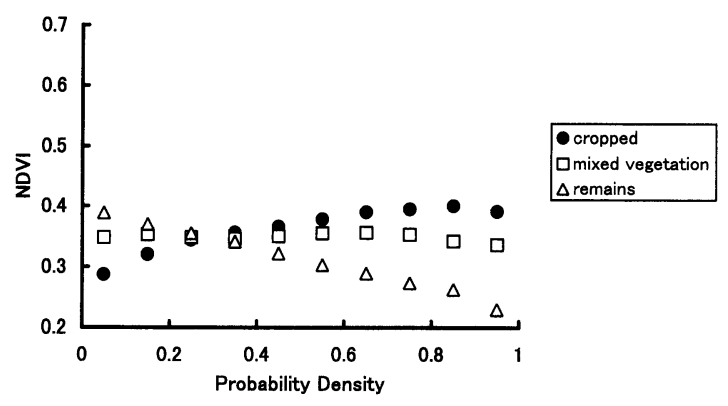

(b) middle ten days of May
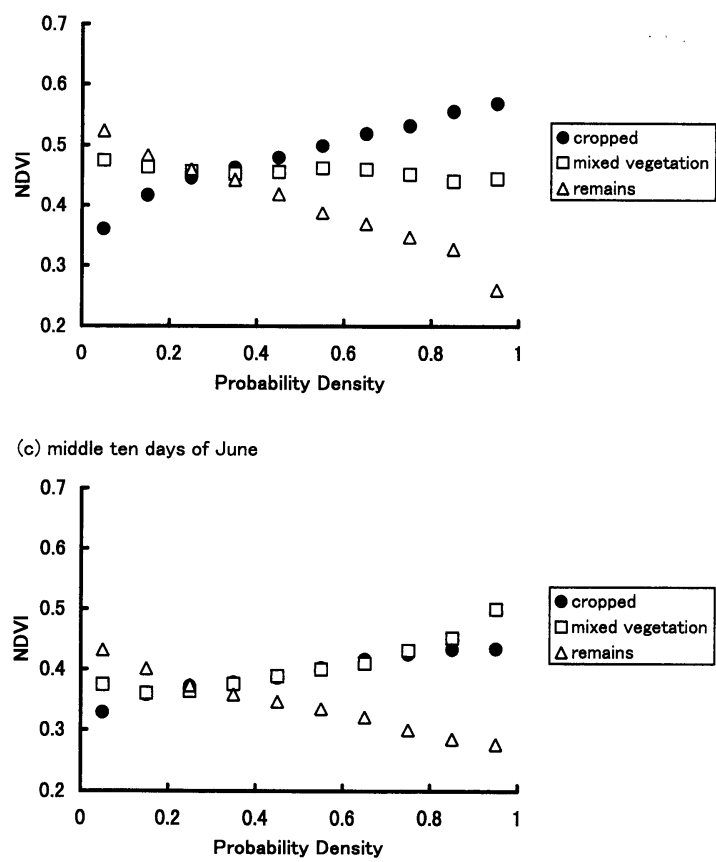

Figure 4 Relation between probability density of portion of land use item and NDVI 


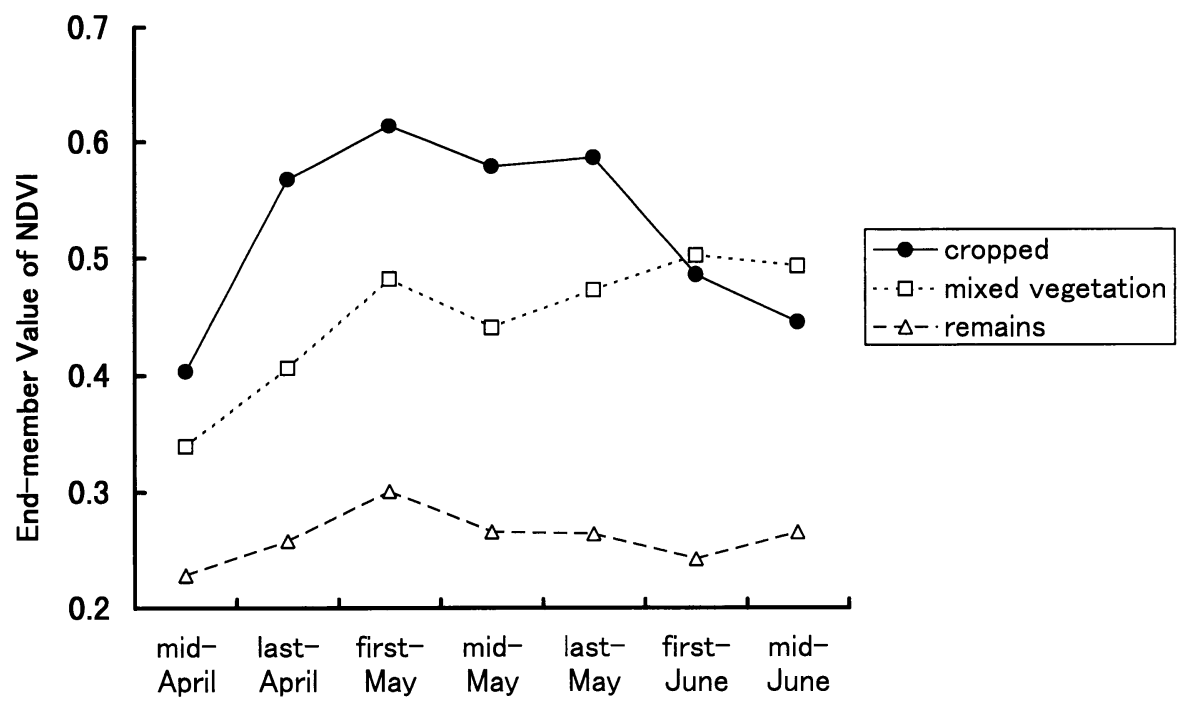

Figure 5 Temporal changes of end-member values for land use items

\subsection{Results of sub-pixel classification}

Results of sub-pixel classification using NOAA/ AVHRR NDVI data would be evaluated by comparison with LANDSAT/TM classification data. Figure 6 shows distribution of probability density for each land use item classified from LANDSAT/TM data, where probability density was calculated within 37 by 37 pixels window.

In this study the author examined the temporal combination of 10-day composite NDVI data for the period from mid-April to mid-June. Table 1 summarizes results of estimation of land use and their correlation coefficient with values estimated by LANDSAT/TM data. Correlation coefficients in the table indicate that the estimation was reasonable for the items of "cropped" and "remains" if the combination of time was appropriate. Estimated amount for these two items tended to be larger than the amount estimated by LANDSAT/TM data. This may be caused by the fact that item "mixed vegetation" contains a kind of agricultural field and bare land, which would be counted in another item. According to the table, temporal combination of "last-April" and "first-June" is the best selection. Figure 7 shows distribution of probability density for each land use item in this case.

Table 2 describes the effects of treatment of low pass filter, i.e., performance of 37 by 37 averaging pixels window, which could mitigate the inconsistency of geometrically referenced position between different temporal data. This table also describes the differences of estimating results by different way of obtaining end-member values.

\subsection{Decision of appropriate temporal combination}

As discussed in chapter 3 , selection of combination of temporal data is significant process in sub -pixel classification. According to the proposed method described in chapter 3 , first the author calculated distances between iso-NDVI lines, $d_{1}$ and $d_{2}$. Table 3 represents distance between iso-NDVI lines, which indicate the difference of NDVI value of 0.1. Table 4 shows amount of area illustrated in Figure 1, which may be called as "Index of Discrimination (IOD)". It could be assumed that the smaller value of IOD should indicate the better combination of temporal NDVI data. This assumption would be acceptable, because correlation coefficient shown in Table 1 had coincidental characteristics with IOD in Table 4.

In practical conditions, it is not realistic to examine every combinations of temporal NDVI for sub -pixel classification. Therefore the author attempted to adopt crop growth model, which described 

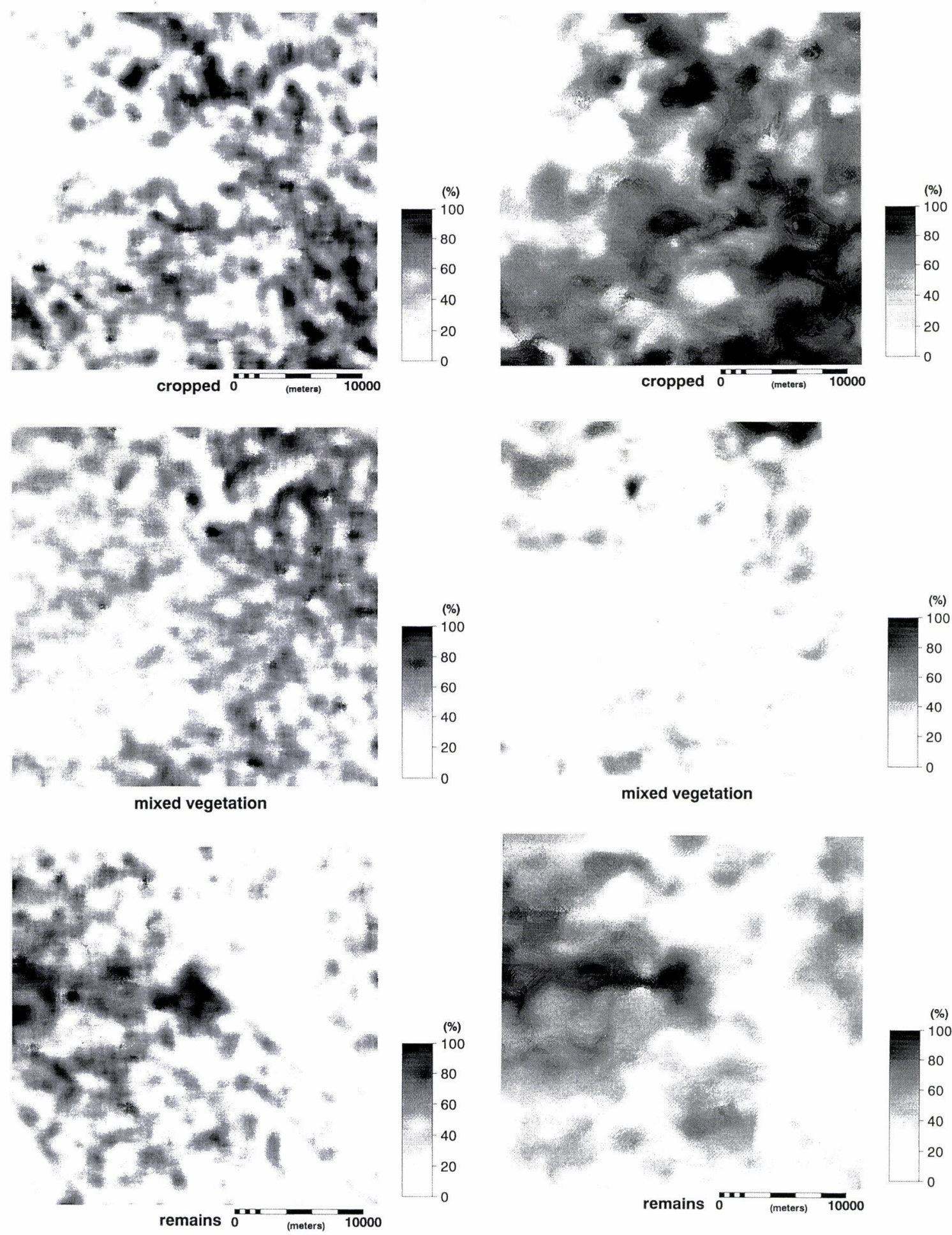

Figure 6 Distribution of probability density for each land use item obtained from LANDSAT/TM

Figure 7 Distribution of probability density for each land use item obtained from NOAA/AVHRR NDVI by sub-pixel classification method 
Table 1 Comparison of sub-pixel classification by different combination of temporal NDVI

\begin{tabular}{|c|c|c|c|c|c|c|c|}
\hline \multicolumn{2}{|c|}{ Combination of time } & \multicolumn{3}{|c|}{ Estimated constitutional ratio (\%) } & \multicolumn{3}{|c|}{$\begin{array}{c}\text { Correlation coefficient with values } \\
\text { estimated by LANDSAT TM }\end{array}$} \\
\hline time 1 & time 2 & cropped & $\begin{array}{c}\text { mixed } \\
\text { vegetation }\end{array}$ & remains & cropped & $\begin{array}{c}\text { mixed } \\
\text { vegetation }\end{array}$ & remains \\
\hline mid-April & last-April & 31.84 & 50.47 & 17.69 & 0.38 & 0.17 & 0.54 \\
\hline mid-April & first-May & 17.14 & 66.16 & 16.70 & 0.04 & 0.07 & 0.43 \\
\hline mid-April & mid-May & 23.45 & $59.4 \overline{5}$ & 17.09 & 0.10 & 0.08 & 0.47 \\
\hline mid-April & last-May & 30.59 & 40.44 & 28.98 & 0.10 & 0.01 & 0.11 \\
\hline mid-April & first-June & 56.39 & 10.50 & 33.11 & 0.52 & 0.09 & 0.73 \\
\hline mid-April & mid-June & 54.95 & 13.10 & 31.95 & 0.48 & 0.19 & 0.74 \\
\hline last-April & first-May & 41.51 & 26.48 & 32.01 & 0.43 & 0.06 & 0.36 \\
\hline last-April & mid-May & 36.89 & 36.09 & 27.02 & 0.37 & 0.07 & 0.27 \\
\hline last-April & last-May & 34.33 & 41.80 & 23.87 & 0.38 & 0.16 & 0.53 \\
\hline last-April & first-June & 51.38 & 13.61 & 35.01 & 0.66 & 0.27 & 0.78 \\
\hline last-April & mid-June & 48.70 & 15.82 & 35.48 & 0.62 & 0.33 & 0.77 \\
\hline first-May & mid-May & 33.93 & 35.53 & 30.54 & 0.10 & -0.06 & 0.14 \\
\hline first-May & last-May & 21.72 & 58.03 & 20.25 & 0.17 & 0.15 & 0.47 \\
\hline first-May & first-June & 47.71 & 17.60 & 34.68 & 0.60 & 0.25 & 0.77 \\
\hline first-May & mid-June & 46.16 & 18.53 & 35.30 & 0.56 & 0.31 & 0.76 \\
\hline mid-May & last-May & 28.52 & 50.05 & 21.44 & 0.21 & 0.13 & 0.49 \\
\hline mid-May & first-June & 50.67 & 14.49 & 34.84 & 0.60 & 0.21 & 0.77 \\
\hline mid-May & mid-June & 48.31 & 16.74 & 34.95 & 0.56 & 0.31 & 0.75 \\
\hline last-May & first-June & 52.33 & 13.48 & 34.19 & 0.50 & 0.08 & 0.75 \\
\hline last-May & mid-June & 50.70 & 15.84 & 33.46 & 0.51 & 0.22 & 0.76 \\
\hline first-June & mid-June & 38.47 & 25.86 & 35.67 & 0.16 & 0.24 & 0.68 \\
\hline \multicolumn{2}{|c|}{ Estimated by LANDSAT TM } & 35.61 & 35.52 & 28.88 & 1 & 1 & 1 \\
\hline
\end{tabular}

Table 2 Comparison of sub-pixel classification by different procedure

\begin{tabular}{|c|c|c|c|c|c|c|c|}
\hline \multicolumn{2}{|c|}{ Combination of time } & \multicolumn{6}{|c|}{ Correlation coefficient with values estimated by LANDSAT TM } \\
\hline \multirow{2}{*}{ time 1} & \multirow{2}{*}{ time 2} & \multicolumn{3}{|c|}{ no treatment of averaged filter } & \multicolumn{3}{|c|}{$\begin{array}{l}\text { application of end-member value obtained } \\
\text { from regression range of } 0-100 \%\end{array}$} \\
\hline & & cropped & $\begin{array}{c}\text { mixed } \\
\text { vegetation }\end{array}$ & remains & cropped & $\begin{array}{c}\text { mixed } \\
\text { vegetation }\end{array}$ & remains \\
\hline last-April & first-June & 0.60 & 0.23 & 0.72 & 0.64 & 0.27 & 0.76 \\
\hline last-April & mid-June & 0.56 & 0.31 & 0.72 & 0.59 & 0.33 & 0.74 \\
\hline first-May & first-June & 0.51 & 0.21 & 0.70 & 0.57 & 0.25 & 0.74 \\
\hline first-May & mid-June & 0.48 & 0.29 & 0.71 & 0.53 & 0.32 & 0.74 \\
\hline mid-May & first-June & 0.49 & 0.18 & 0.69 & 0.57 & 0.21 & 0.74 \\
\hline mid-May & mid-June & 0.47 & 0.29 & 0.70 & 0.53 & 0.31 & 0.73 \\
\hline last-May & first-June & 0.41 & 0.08 & 0.67 & 0.44 & 0.09 & 0.70 \\
\hline last-May & mid-June & 0.43 & 0.20 & 0.71 & 0.46 & 0.23 & 0.74 \\
\hline
\end{tabular}


Table 3 Distance between iso-NDVI lines which indicate the difference of value of 0.1

\begin{tabular}{|c|c|}
\hline Time & Distance \\
\hline mid-April & 0.7960 \\
\hline last-April & 0.4562 \\
\hline first-May & 0.4499 \\
\hline mid-May & 0.4508 \\
\hline last-May & 0.4328 \\
\hline first-June & 0.4852 \\
\hline mid-June & 0.5897 \\
\hline
\end{tabular}

temporal changes of NDVI by analytical formula, to decide the appropriateness of combination of temporal NDVI.

Temporal changes of NDVI of winter wheat can be generally expressed by using double logistic function. This was supported by the discussions on applicability of this function for representing growth of major crops in France by Fischer ${ }^{9) 10)}$. Simple logistic function can fit to express temporal changes of NDVI of mixed vegetation in spring season because decreasing feature of NDVI in autumn season was not covered in the temporal range of analysis. A little increasing line can fit to remains because the amplitude of increase of NDVI for this item was not remarkable.

The parameters in formula described below were obtained by using data in Figure 3. In this process parameters which corresponded to minimum and maximum values of NDVI were a priori set to -0.1 and 0.6 for winter wheat by observing the tendency depicted in Figure 3. Similarly minimum and maximum values were set to -0.1 and 0.2 for mixed vegetation. Remaining parameters were determined by minimization of root mean square of deviation using data in Figure 3. These formulas are also illustrated in Figure 8.

$$
\begin{aligned}
& N D V I_{W W}(t)=-0.1+\frac{0.7}{1+\exp (-0.1196 \times(t-99))} \\
&-\frac{0.7}{1+\exp (-0.1181 \times(t-155))} \\
& N D V I_{M V}(t)=-0.1+\frac{0.3}{1+\exp (-0.0745 \times(t-117))} \\
& N D V I_{o}(t)=0.0005 t-0.1023
\end{aligned}
$$

\begin{tabular}{|c|c|c|}
\hline \multicolumn{2}{|c|}{ Combination of time } & \multirow{2}{*}{$\begin{array}{c}\text { Area } \\
\text { (Index of Discrimination) }\end{array}$} \\
\hline time 1 & time 2 & \\
\hline mid-April & last-April & 2.0702 \\
\hline mid-April & first-May & 5.9745 \\
\hline mid-April & mid-May & 4.2316 \\
\hline mid-April & last-May & 20.8631 \\
\hline mid-April & first-June & 0.9342 \\
\hline mid-April & mid-June & 0.8682 \\
\hline last-April & first-May & 1.7679 \\
\hline last-April & mid-May & 2.2524 \\
\hline last-April & last-May & 1.0302 \\
\hline last-April & first-June & 0.3906 \\
\hline last-April & mid-June & 0.3957 \\
\hline first-May & mid-May & 8.1378 \\
\hline first-May & last-May & 2.5481 \\
\hline first-May & first-June & 0.4672 \\
\hline first-May & mid-June & 0.4496 \\
\hline mid-May & last-May & 1.9271 \\
\hline mid-May & first-June & 0.4471 \\
\hline mid-May & mid-June & 0.4358 \\
\hline last-May & first-June & 0.5272 \\
\hline last-May & mid-June & 0.4846 \\
\hline first-June & mid-June & 1.9805 \\
\hline
\end{tabular}

Figure 9 shows distribution of IOD calculated by using formulas of crop growth model as mentioned

Table 4 Area of intersection (Index of Discrimination) composed of 2 temporal iso-NDVI lines 


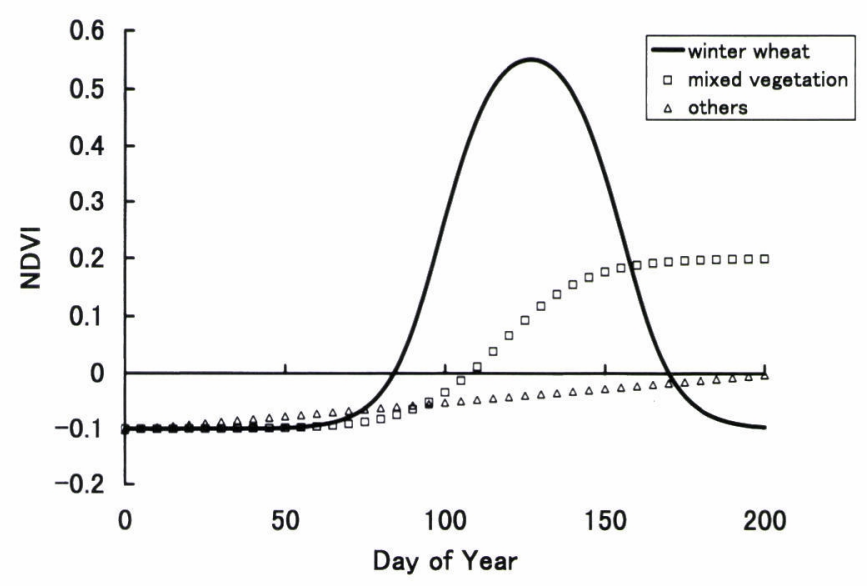

Figure 8 Temporal profile of NDVI for land use items calculated by using crop growth model

above. The most appropriate temporal combination appears around the position of 125-days and 175 days of year, i.e., first-May and last-June. In actual case of the site, summer crops would be planted in around June and their contribution to the value of NDVI could not be neglected after middle of June. If we do not consider the results after 160 -days of year, the most appropriate temporal combination should be consistent with the results shown in Table 1.

\section{Discussions}

In this study the results of estimation of land use

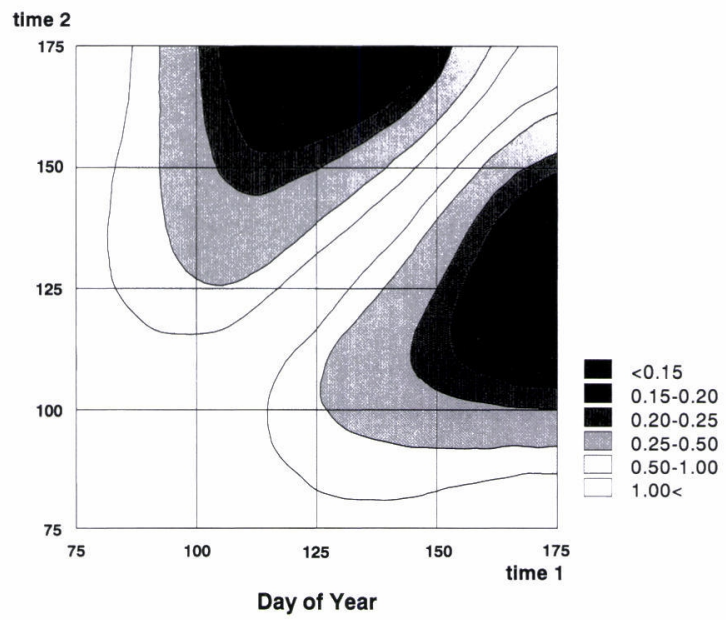

Figure 9 Distribution of Index of Discrimination calculated by using crop growth model components by sub-pixel classification method were acceptable in terms of improvement for existing approach to compile dataset of wide area. However it has not yet established a set of methods and procedures for accurate estimation of acreage of specific land use item such as winter wheat. Probably one of the significant constraints of this method is how to define land use items. For example, vegetation conditions of the area classified as bare land at one time cannot be expected after some period. Case of this study also showed that rice would plant on a part of bare land and this presumably affected the results of estimation.

Increasing number of land use items may be a feasible way to improve the method. This should be attained in condition that temporal profile of NDVI for each land use has distinctively separable features and that necessary numbers of temporal NDVI data in appropriate time are given. In case of land use items becomes more than four, a method to calculate IOD would be modified. One considerable way is to calculate summation of IOD values for ${ }_{n} C_{3}$ combinations of three land use items within total $n$ items. In order to realize this improvement, the more efforts should be required for observation and examination of land use legend appeared in various regions in consideration with application of sub -pixel classification.

Estimation of land use by sub-pixel classification 
method described in this paper is rather sensitive against changes of end-member values. End-member values are usually determined by comparison with land use information derived from high spatial resolution satellite data or other geographical data sources. Even end-member values at the specific area are properly determined, extrapolation to other area would be problematic issue of applying sub-pixel classification method. Therefore it is effective to define areas and their geographical extent, where land use conditions show similar features in temporal scheme.

Another disputing problem should be the point of accuracy of geo-reference. Sub-classification method hypothesizes that each temporal data can be overlaid at the same location. However it may not be realistic if we request an accuracy of less than one meter for NOAA/AVHRR data, for example. One feasible treatment for this problem is to smooth the margin of pixels and it had been proven in this case study as shown in Table 2 .

\section{Conclusion}

This article introduced sub-pixel classification method of land use, which is applicable to coarse resolution satellite data such as NOAA/AVHRR. This method utilizes the characteristics of temporal profile of NDVI for each land use item. Through the case study of winter wheat production area in China, this method could estimate reasonably distribution of winter wheat cultivation area and other land uses. The author also proposed an index to evaluate appropriateness of combination of temporal data used in this method. This index rationally supported to select the combination of data in this study.

In order to apply this sub-pixel classification method in monitoring land use for wide area operationally, many efforts on examining the conditions and limitations should be required. However, it should be rational to publish about the attempt of this approach, because land use information in more detail in both spatial and temporal domain has been expecting by a lot of organizations for better understandings of global environmental issues.

\section{Acknowledgements}

This research has been implemented as a part of Chinese Academy of Agricultural Sciences (CAAS) and JIRCAS collaborative research program. The author would like to acknowledge Drs. Zhou Qinbo and Chen Youqi, Institute of Natural Resources and Regional Planning, and Dr. Zhang Weili, Soil and Fertilizer Institute, for their contribution to the program.

(受付日2000.9.21, 受理日2001.1.22)

\section{References}

1 ) Cross, A.M., J.J. Settle, N.A. Drake and R.T.M. Paivinen: Subpixel measurement of tropical forest cover using AVHRR data, Int. J. Remote Sensing, 12(5), 1119-1129, 1991.

2) Holben, B.N. and Y.E. Shimabukuro: Linear mixing model applied to coarse spatial resolution data from multispectral satellite sensors, Int. J. Remote Sensing, 14(11), 2231-2240, 1993.

3 ) Quarmby, N.A., J.R.G. Townshend, J.J. Settle, K.H. White, M. Milnes, T.L. Hindle and N. Silleos: Linear mixture modelling applied to AVHRR data for crop area estimation, Int. J. Remote Sensing, 13(3), 415-425, 1992.

4 ) Puyou-Lascassies, P., G. Flouzat, M. Gay and C. Vignolles: Validation of the use of multiple linear regression as a tool for unmixing coarse spatial resolution images, Remote Sens. Environ., 49, 155-166, 1994.

5 ) Kerdiles, H. and M.O. Grondona: NOAA -AVHRR NDVI decomposition and subpixel classification using linear mixing in the Argentinean Pampa, Int. J. Remote Sensing, 16(7), 1303-1325, 1995.

6 ) Ouaidrari, H., A. Bégué, J. Imbernon and J.M. D'Herbes: Extraction of the pure spectral response of the landscape components in NOAA -AVHRR mixed pixels -application to the 
HAPEX-Sahel degree square, Int. J. Remote Sensing, 17(12), 2259-2280, 1996.

7 ) Faivre, R. and A. Fischer : Predicting crop reflectances using satellite data observing mixed pixels, J. Agricul. Biol. Environ. Statistics, 2(1), 87 $-107,1996$.

8 ) Olesen, K.W., S. Sarlin, J. Garrison, S. Smith, J. L. Privette and W.J. Emery: Unmixing multiple land-cover type reflectances from coarse spatial resolution satellite data, Remote Sens. Environ., 54, 98-112, 1995.

9 ) Fischer, A.: A model for the seasonal variations of vegetation indices in coarse resolution data and its inversion to extract crop parameters, Remote Sens. Environ., 48, 220-230, 1994.

10) Fischer, A. : A simple model for the temporal variations of NDVI at regional scale over agricultural countries. Validation with ground radiometric measurements, Int. J. Remote Sens- ing, 15(7), 1421-1446, 1994.

11) Moulin, S., A. Fischer, G. Dedieu and R. Delécolle: Temporal variations in satellite reflectances at field and regional scales compared with values simulated by linking crop growth and SAIL models, Remote Sens. Environ., 54, 261-272, 1995.

12) Uchida, S., R. Roohi and S. Ahmad: Land degradation analysis of rainfed agricultural area in Pakistan using remote sensing data, Proc. $15^{\text {th }}$ Asian Conf. Remote Sensing, C-4, 1-5, 1994.

13) Uchida, S.: Extraction of soil characteristics and monitoring of agricultural land use in the semi-arid tropics of India using remote sensing, JIRCAS J., 6, 39-52, 1998.

14) Eidenshink, J.C. and J.L. Faundeen: The 1-km AVHRR global land dataset: first stages in implementation, Int. J. Remote Sensing, 15(17), 3443-3462, 1994. 